\title{
Media's Broader Roles in Mitigating COVID-19
}

\author{
Tsuroyya* \\ Communication Science Department, \\ Faculty of Social Sciences and Law, \\ Universitas Negeri Surabaya, \\ Surabaya 60231, Indonesia \\ tsuroyya@unesa.ac.id
}

\author{
Danang Tandyonomanu \\ Communication Science Department, \\ Faculty of Social Sciences and Law \\ Universitas Negeri Surabaya \\ Surabaya, Indonesia \\ danangtandyonomanu@unesa.ac.id
}

\author{
Gilang Gusti Aji \\ Communication Science Department, \\ Faculty of Social Sciences and Law \\ Universitas Negeri Surabaya \\ Surabaya, Indonesia \\ gilangaji@unesa.ac.id
}

\begin{abstract}
A declaration of public health emergency of international concern on Coronavirus disease (COVID-19) by the World Health Organization (WHO) has challenged mass media to better represent health and illness regarding the global pandemic more proportionally. This study aims at exploring the top priorities of media mitigation on COVID-19 proposed by communication students. Media is found as a reliable source of updated information and public communication campaign on healthier life. Findings suggest a broader role of media is necessary to resolve the pandemic as well as to encourage individual's survival both psychologically and physically. Such role entails the provision of accurate data for public and World Health Organization (WHO) consumption. At the same time media is required to report good news occurred to maintain optimism among individuals. The next crucial role is to continuously promote preventive behaviours as a part of new normal during the pandemic era. The last involves media-based crowdfunding to help those affected by the pandemic. It is then necessary to test whether or not those roles mitigate the pandemic in future research.
\end{abstract}

Keywords: Media, role, mitigation, COVID-19

\section{INTRODUCTION}

After an unprecedented case occurred in Wuhan, China, World Health Organization (WHO) declared new corona virus disease further known as COVID-19 as international public health emergency[1]. The virus is easily transmitted to humans through droplets and physical contacts with infected patients[1]-[5]. To avoid a greater outbreak and flatten the curve, WHO campaigns hygiene life style and new behaviors to be adopted by people [1]. Wearing a mask, washing hands thoroughly, avoiding mass gatherings, and maintaining a distance whilst interacting with others are primary acts enforced to contain the outbreak[3].Therefore, health communication and social marketing play crucial a role to both control the virus and boost massive campaign on the so-called 'new norm'[2], [6].
However, substantial research on COVID-19 mainly discusses different treatments applied to infected patients, a variety of responses from countries to deal with the virus, effects of COVID-19 to both economy and education sectors[7], [8]. The latter unfortunately has been affected badly in a way that educators, students, and parents are forced to use information and communication technology as the main tool of learning process at home[8]. On the other hand, parents are also required to have pedagogic competence whilst accompanying their children studying. Limited access to the internet and smartphones have caused students drop out from schools. As a result, many schools particularly early childhood schools are forced to close due to unavailability of students[9].

Rather than investigating health campaigns, scholars highlight effects resulted from media coverage in shaping knowledge, in particular, pharmacists. In fact, even though the pharmacists have high knowledge of the disease, it has been proved that they likely to have high risk perception of the virus due to media exposure[2]. Due to rigorous information on COVID-19 with less control from gatekeepers, people often times merely type and search the most current news of the virus. A case study from Taiwan has proved the usage of google trend search is effective for risk communication during the pandemic[10].

Few scholars have discussed how media could mitigate the pandemic leading to a contained the outbreak, adopted new behaviors, and a growth in economy. Therefore, this study aims at investigating media mitigation during the pandemic particularly in Indonesia proposed by students. There are four potential mitigation frameworks that can be applied to control the pandemic. The first is a strong collaboration between media, Indonesian government, and WHO to provide accurate COVID-19 data. Next is encouragement of optimism and resilience among individuals to fight the virus together. Another main agenda of media COVID19 mitigation involves massive campaign on hygiene lifestyle and new behaviors. The final strategy to boost in-country's growth of economy, media is the most 
influential tool to generate crowdfunding and charities in order to help those affected by the pandemic.

\section{METHODS}

The study employed a qualitative approach aiming at exploring potential ways to mitigate the pandemic proposed by students. The date were taken from students' essays submitted for a media and social change course in Spring Semester 2019/2020. The essay should at least provide three possible strategies along with their rationale to be implemented by the Indonesian government. Out of 22 students, 21 essays were submitted timely through a google classroom since the class was conducted using a blended learning mode due to a university lockdown. The data then were processed using thematic analysis.

\section{RESULTS AND DISCUSSION}

\section{A. Tri-Partite Collaboration between Media, the Government, and $\mathrm{WHO}$}

Among few countries which successfully respond to the pandemic are Taiwan, New Zealand, and Germany. Their government work closely with WHO and media to provide updated data on the spread of the infection. That is the government provide access to immediate stakeholders, WHO, health ministry, and media to monitor the data. Students believed that transparency and accuracy in terms of COVID-19 data were crucial. Hence, the Indonesian government should adopt a similar approach to prepare both preventive and curative actions toward the virus.

In this case, media's role is both as a mediator between stakeholders and a source of information for public. To disseminate health information, both media and government must consider four key elements. The first is honest and open statements of what's being controlled and uncontrolled as well as facts-oriented. Next is being consistent and specific in informing COVID-19 data. The pandemic also requires an ability to decide confidently and honestly. The last element is information should be emphatic in a way that both media and government acknowledge public's emotion [5].

\section{B. Encouragement of Optimism and Resilience among Individuals}

Students suggested several ways that media could adapt in showing encouragement to public optimism and resilience. One is to keep informing good news amidst the pandemic. The good news somehow resonates confidence and a positive vibe to public [5]. Other approach such as showing various coverages to support health practitioners who are still fighting the virus is perceived to be useful for maintaining public resilience. Recent studies argue that being able to interact with patient's and health practitioner's family can boost their spirit for during the videocall they encourage each other [11]. The next strategy that media can adopt involves features informing various fun and indoor activities while experiencing lockdown. Broadcasting such news may reduce stress and being lonely among individuals.

Borrowing from research investigation on applying Health Belief Model employed by community pharmacists, media will have a direct role in exposing perceived benefits, self-efficacy and cues to actions in combatting COVID-19 to public[3]. This positive information then leads to public optimism and awareness that "we are in this situation together." Again when media plays a broader role in a way that it mitigates the emergency situation, individuals may take further health measures to prevent the virus. Scholars have claimed that patients who use health services generated by media are likely to seek information from doctors[12].

\section{Massive Campaign of Preventive Behaviours as the "New Norm"}

Another top priority media mitigation proposed by students' essays involves massive campaign of new behaviors to be adopted and/ or reinforced by individuals during the pandemic. Producing a standardized public service announcement (PSA) of washing hands, coughing, sneezing, and wearing masks is deemed necessary since this PSA will be broadcast worldwide. Considering a broad target audience, media needs to carefully determine which channel is suitable for different age group. The students suggested such PSA could be disseminate through social media, e.g. Line, Instagram, and Twitter for younger individuals.

In order to contain the virus, individuals must implement physical distancing. Therefore, students argued that a massive campaign on this issue is necessary particularly for youngsters who are fond of hanging out with friends. This is in line with recent investigation which has recommended Mass Gathering (MG) cancellation for the MG is potentially jeopardized by the outbreak [13]. Therefore, media should highlight the importance of staying at home most of the times to flatten the curve. Most importantly, the media should introduce this shared belief to public in the campaign [14]. 


\section{Crowdfunding as a Solution of Affected Economy}

The students believed that media could outweigh its role in a way it instills empathy among individuals. In other words, media could initiate live programs embedded with open donations/ charities which contribute to the pandemic mitigation. As some student suggested, a oneday live concert of specific entertainer could generate five billion Indonesian rupiahs. The fund will then be distributed to those affected by pandemic financially, and health practitioners in forms of personal protective equipment and medical masks. On the other hand, it is important to note that those who are affected by COVID-19 are most likely women. Therefore, media should also include them in preparing the intervention, particularly in getting access to healthcare and financial support[15].

The motto of 'sharing means caring' was also suggested by the students so that each individual could contribute to the safety of its own community. The essays further elaborated that a local community plays an important role to fight the new coronavirus. Once an individual gets infected, his local community will help him in terms of meals supply and encouragement so that he will be in good health soon. In this case, media could manage a specific program showing local community empowerment during the pandemic[4], [6].

\section{CONCLUSION}

During the pandemic, media is seen as a potential tool not only to inform, but also to mitigate the new coronavirus outbreak. Students' essays show that media could play a broader role to help both government and public contain the virus. Its role involves building a strong collaboration with the Indonesian government and WHO in providing accurate data transparently, encouraging public optimism and resilience, continuously promoting new behaviors to be adopted by each individual, and generating media-based crowdfunding to help those affected by the pandemic. The findings contribute to media scholarship particularly its broader role to play during the public emergency situation. Future research on whether or not such role can mitigate the pandemic effectively is worth investigated.

\section{REFERENCES}

[1] C. Sohrabi et al., "World Health Organization declares global emergency: A review of the 2019 novel coronavirus (COVID-19)," Int. J. Surg., vol. 76, no. February, pp. 71-76, 2020.

[2] R. Karasneh, S. Al-Azzam, S. Muflih, O. Soudah, S. Hawamdeh, and Y. Khader,
"Media's effect on shaping knowledge, awareness risk perceptions and communication practices of pandemic COVID-19 among pharmacists," Res. Soc. Adm. Pharm., no. April, 2020 .

[3] R. Carico, J. Sheppard, and C. B. Thomas, "Community pharmacists and communication in the time of COVID-19: Applying the health belief model," Res. Soc. Adm. Pharm., no. March, pp. 1-4, 2020.

[4] C. H. Basch, G. C. Hillyer, Z. M.- Erwin, J. Mohlma, A. Cosgrove, and N. Quinones, "News coverage of the COVID-19 pandemic: Missed opportunities to promote health sustaining behaviors," Res. Soc. Adm. Pharm., pp. 1-5, 2020.

[5] A. Finset et al., "Effective health communication - a key factor in fighting the COVID-19 pandemic," Patient Educ. Couns., vol. 103, no. 5, pp. 873-876, 2020.

[6] V. Marinescu and B. Mitu, The Power of the Media in Health Communication. London: Routledge, 2016.

[7] S. Krishnamurthy, "The future of business education: A commentary in the shadow of the Covid-19 pandemic," J. Bus. Res., vol. 117, no. May, pp. 1-5, 2020.

[8] E. Beaunoyer, S. Dupéré, and M. J. Guitton, "COVID-19 and digital inequalities: Reciprocal impacts and mitigation strategies," Comput. Human Behav., vol. 111, no. May, 2020.

[9] N. Hasan and Y. Bao, "Impact of 'e-Learning Crack-up' Perception on Psychological Distress among College Students During COVID-19 pandemic: A mediating Role of 'Fear of Academic Year Loss," Child. Youth Serv. Rev., vol. 118, no. August, p. 105355, 2020.

[10] A. Husnayain, A. Fuad, and E. C.-Y. Su, "Applications of google search trends for risk communication in infectious disease management: A case study of COVID-19 outbreak in Taiwan," Int. J. Infect. Dis., 2020.

[11] A. Negro et al., "Introducing the Videocall to facilitate the communication between health care providers and families of patients in the intensive care unit during COVID-19 pandemia," Intensive Crit. Care Nurs., p. 102893, 2020.

[12] J. Xiang and S. J. Stanley, "From online to offline: Exploring the role of e-health 
consumption, patient involvement, and patientcentered communication on perceptions of health care quality," Comput. Human Behav., vol. 70, pp. 446-452, 2017.

[13] Q. A. Ahmed and Z. A. Memish, "The cancellation of mass gatherings (MGs)? Decision making in the time of COVID-19," Travel Med. Infect. Dis., p. 101631, 2020.

[14] C. Calderon, "The importance of shared beliefs for social marketing programmes," J. Soc. Mark., vol. 9, no. 1, pp. 26-39, 2019.

[15] C. Wenham, J. Smith, and R. Morgan, "COVID-19: the gendered impacts of the outbreak," Lancet, vol. 395, no. 10227, pp. 846-848, 2020. 